Esta revista forma parte del acervo de la Biblioteca Jurídica Virtual del Instituto de Investigaciones Jurídicas de la UNAM www.juridicas.unam.mx

http://biblio.juridicas.unam.mx

\title{
LUSOPHONE JURISPRUDENCE IN IBEROAMERICAN LEGAL PHILOSOPHY*
}

\author{
FILOSOFÍA DEL DERECHO LUSITANA EN EL CONTEXTO \\ DE LA FILOSOFÍA DEL DERECHO IBEROAMERICANA
}

Paulo FERREIRA DA CUNHA**

\section{Resumen:}

Muchos autores, en el campo de la filosofia, han defendido la existencia de una filosofia luso-brasileña. Hay incluso un Instituto de Filosofia Luso-Brasileña (Instituto de Filosofia Luso-Brasileira) que organiza de manera alternada cada año - entre otras actividades y publicaciones- el coloquio Tobias Barreto en Portugal, y el coloquio Antero de Quental en Brasil.

La idea central de este trabajo es aplicar el mismo paradigma de filosofias inter-nacionales (basadas en una lengua común y en el diálogo permanente debido a su herencia cultural) a la filosofia del derecho, especialmente la filosofia del derecho no universitaria (la universitaria parece ser más cosmopolita). ¿Existe una filosofia jurídica luso-brasileña? ¿Y, de ser el caso, cuál podría ser el lugar que ocupa en el contexto de una filosofia jurídica latinoamericana?

\footnotetext{
* Some of our previous works, already approached the question, such as our books Temas e Perfis da Filosofia do Direito Luso-Brasileira, Lisboa, Imprensa Nacional-Casa da Moeda, 2000 and Pensamento Jurídico Luso-Brasileiro, Lisboa, Imprensa Nacional - Casa da Moeda, 2006 and the more recent article: Do Jusracionalismo Luso-Brasileiro e da Unidade Essencial do Jusnaturalismo - Reflexão Problemática Filosófico-Histórica, in "Collatio", num. 12, September-December 2012, pp. 17-30, electronic version: http://www.hottopos.com/collat12/17-30 FC.pdf.

** Ph D Univ. Paris II, Univ. Coimbra. Full Professor, Oporto University, Portugal, Interdisciplinary Juridical Institute, Director, lusofilias@gmail.com
}

\section{PROBLEMA}

Anuario de Filosofia y Teoría del Derecho, Núm. 8, enero-diciembre de 2014, pp. 125-146 $\underline{125}$ 
Esta revista forma parte del acervo de la Biblioteca Jurídica Virtual del Instituto de Investigaciones Jurídicas de la UNAM www.juridicas.unam.mx

http://biblio.juridicas.unam.mx

\author{
PAULO FERREIRA DA CUNHA
}

Hasta ahora, la investigación nos permite concluir que hay un gran universo de estudios en espera de nuevos investigadores.

\title{
Palabras clave:
}

Filosofia del derecho lusitana, antiguas libertades ibéricas, filosofias nacionales, filosofia del derecho iberoamericana, recepción de la filosofia del derecho.

\begin{abstract}
:
Several authors in the field of pure philosophy have argued the existence of a Luso-Brazilian philosophy. There is even a Luso-Brazilian Institute of Philosophy (Instituto de Filosofia Luso-Brasileira) that has important activities such as publications, and the organization of the colloquium Tobias Barreto in Portugal, and the colloquium Antero de Quental in Brazil.

The central idea of this paper is to apply the same paradigm of inter-national philosophies (based on common language, and lasting dialogue at the cultural heritage level) to the philosophy of law, especially the non-academic one (the academic seems to be more cosmopolitan). Therefore we pose the question: Is there a Luso-Brazilian legal philosophy? And if there is, what is its place in the context of Latin American legal philosophy?
\end{abstract}

\section{Keywords:}

Lusophone Jurisprudence, Old Iberian Liberties, National Philosophies, Iberoamerican Legal Philosophy, Jurisprudential Reception. 
Esta revista forma parte del acervo de la Biblioteca Jurídica Virtual del Instituto de Investigaciones Jurídicas de la UNAM www.juridicas.unam.mx

http://biblio.juridicas.unam.mx

LUSOPHONE JURISPRUDENCE IN IBEROAMERICAN LEGAL PHILOSOPHY

"Sobre estos dos pilares fundamentales está basada
la historia iberoamericana: el primero como simbolo
de la grandeza y de la justicia; el segundo como
simbolo de la libertad y comprensión humana para
la convivencia pacífica de estos grandes pueblos que
miran al futuro, puestas sus miras en aquellas
justicia y en aquella paz que tanto ansian las na-
ciones".

Lázaro SÁNCHEZ1

Summary: I. The Old Iberian Liberties. II. The Problem of National Philosophies. III. In the Quest of Specifities. IV. Non Juridical Jurisprudence. V. Brazilean Memoirs. VI. What is Really in Common? VII. Bibliography.

\section{The Old IBERIAN LIBERTIES}

In Iberia (or Hispania), a peninsula which later would expand and give birth to the Iberoamerican (Hispanoamerican) world (and other social and sociological and cultural fruits of other diasporas and new communities), we may very clearly see a strong feeling of honor and personal dignity.

The Portuguese poet and former lawyer Teixeira de Pascoaes, friend and comrade of letters with Miguel de Unamuno and other Spanish writers, called our attention to the fact that, while in Northern Europe countries still made human sacrifices to pagan gods, we already imposed our kings a contratual form: rex eris si recte facies, si non facies non eris. And it was not a mere retorical formula: it happened that bad kings were deposed and replaced. In Portugal in the XIIIth and XVIIth centuries that concretely happened: kings Sancho II and Afonso VI were deposed, just to give two main examples.

1 Sánchez, Lázaro, "Prólogo" to Historia de Iberoamerica, by Manuel Rodríguez Lapuente, Barcelona, Ramon Sopena, 1983, p. 8. 
Esta revista forma parte del acervo de la Biblioteca Jurídica Virtual del Instituto de Investigaciones Jurídicas de la UNAM www.juridicas.unam.mx

http://biblio.juridicas.unam.mx

PAULO FERREIRA DA CUNHA

This Idea of honor and dignity (capable, in its negative side, of moments of arrogance and even hubris - that are already part of History) are the principium sapientiae of a Law really worthy of that name. Eventually with some anachronism or "chronocentrism", we would say these traits maybe seem too modern, or avant-la-lettre. In fact, we use to consider those ideas as contemporary or at least modern. But it depends on the style and colours they show... Not allways these concepts are very rigourous in the current textbooks and alike. If the old constitutionalism, pre-modern one, is present in those academic books, that fact is that for many years it was almost absent or in the shadows. And the coexistence of Lassalle's historico-universal concept of constitution with some hidden or shadow prejudices against old and material constitutions seemed not to bother anyone.

Let's put some questions to these paradigms. How came into life this specific legal culture, which will even cross the oceans?

Surely it was built from many different materials: Roman law, of course, Christianity (the idea of equality, as it is nowadays remembered for instance by Luc Ferry, is difficult to conceive in cultures long deprived of the Christian legacy or allien to it), and also Visigothic legacy... But a deeper study of how and why this vision of Law was born still seems to await the interest of researchers.

And what is the style proper to the common law of the peoples of the Iberian Peninsula? May we dare to ask that?

We seem to have a constant concern for the practical protection of the rights of every man. This way of seeing people and protecting them is older than the other forms of protection: English, American, French, the other ways of protection, as the constitutional revolutions of modernity put it, and the most epic subsequently recorded by History.

The old Iberian freedoms symbolized by the councils of Toledo, and the major figure of Isidore of Seville, symbolize the seed of humanistic concern with the legal person and his or her rights, freedoms and guarantees. The old Iberian 
Esta revista forma parte del acervo de la Biblioteca Jurídica Virtual del Instituto de Investigaciones Jurídicas de la UNAM www.juridicas.unam.mx

http://biblio.juridicas.unam.mx

LUSOPHONE JURISPRUDENCE IN IBEROAMERICAN LEGAL PHILOSOPHY

freedoms have not, admittedly, the magnitude or even the rhetorical paradigm shift key. As it is well known, this anthropological revolution in the Western World was wrought by the Kantian sapere aude motto, and is commonly expressed by the sacred ternary Liberty, Equality, Fraternity, with wich the French Revolution and its daughters would convert the world and built the Modern Liberal Democratic State. And, of course, the Social State, too.

But the Iberian liberties are a significant form of protection of Person, and above all have a concrete sense: practical, and effective. The bureaucratic systems that the world entangled makes this old one (in a sense) contemporary, as a window and an example of another way of protection. Some excess of legal mechanisms make constitutional, civil and human rights and principles (the main juridical forms we have today) almost dead letter. But let's not to confuse abstract bureaucracy with constitucional remedies, that are effective instruments of freedom and constitutionality.

\section{The Problem of National Philosophies}

From the ancestral practice of respect for the person, care for the dignity of the person, we can move on to the specific philosophical relationship with law.

There are obviously critical positions to the existence of national philosophies. But the problem has also been solved in many cases positively, in all areas where people speak Portuguese and Spanish.

There are, of course, different philosophies in different countries: some are totally foreign (the name in Portuguese to an intellectual who renies his ou her roots to became a foreign influenced person is "estrangeirado", and it has often - but not allways - a pejorative conotation), but some other are the philosophies of those countries (and of continents and of cultural communities, as the Lusophone or Iberoamerican). 
Esta revista forma parte del acervo de la Biblioteca Jurídica Virtual del Instituto de Investigaciones Jurídicas de la UNAM www.juridicas.unam.mx

http://biblio.juridicas.unam.mx

PAULO FERREIRA DA CUNHA

At least, if there are possibilities for the design of those philosophies as nationally or culturally based, so they exist. This Cogito is valid, because they are, by nature, mental constructs. The opposite idea states that philosophy is by definition universal, so it would be impossible to have national or cultural particular philosophies. But what is curious to observe is that, in general, the same who reserve philosophy for universal purpose don't seem to be disturbed with "things" such as Indian philosophy, or Chinese phylosophy... Even Ancient Greek philosophy doesn't seem to be a wrong qualification for them. Would it be a precaution against nationalisms? And specifically Western and (of course) contemporary ones? Vain precaution... so it seems.

\section{In THE QUeST OF SPECIFICITIES}

Let's try to approach our subject step by step. What would be specific of the Portuguese philosophy, the one we have more obligation to know, among all these?

It is not easy to answer... Because what seems to be peculiar, could also be vindicated by other countries, probably.

The traditional sense and genuine legal philosophy in Portugal is a constant concern for Justice and Human, which runs through its entire history, with no real interregnum. This coherence can be detected even during a long time, in Middle Ages as in the Modern times. And this seems to be a point to invalidate the theory that advocates a sharp and radical distinction "classic/modern" (especially in the field of Law Natural). So, even very late (even during the Enlightenment period) the law was commonly identified, in line with classical realism, as the suum cuique tribuere.

If ideas may not be enough, or may be considered vague, what about blood? Could we consider that the philosophy of a country or of a culture is the one of the people who was 
Esta revista forma parte del acervo de la Biblioteca Jurídica Virtual del Instituto de Investigaciones Jurídicas de la UNAM www.juridicas.unam.mx

http://biblio.juridicas.unam.mx

LUSOPHONE JURISPRUDENCE IN IBEROAMERICAN LEGAL PHILOSOPHY

born there, that is to say, the one concieved by native citizens? Of course this is a non philosophical criterium.

In many respects, and especially given the mobility and interpenetration of cultures in Europe, crossed by migrations of diverse order, this is not even a practical way of defining legal cultures or legal philosophies.

Baruch of Spinoza (or Bento de Espinosa...) is casually natural from Netherlands (but it seems that he thought in Portuguese). Shall we consider him a Dutch philosopher by ius soli or a Portuguese (or a Jew) philosopher by the ius sanguinis? This seem so irrelevant as the quarrel about Colombo's nationality. He was an European, one of the first Europeans. And so was Spinoza... or Espinosa.

But sometimes some country wants the adoption of heroes or philosophers... There are, for example, a mythological and fanciful version on the Lusitanity of Aristotle (he would be born in Lusitania, and then went to Greece: how convenient to Portuguese pride!). This is indicative of the attachment of the Portuguese to the Stagirit. But also it means that this is, at least in some periods and for certain minds, such an important question that it may be falsified, in myth.

In fact, we have not only the ius soli or ius sanguinis criteria to establish the nationality of a culture. It has been discussed, for example, about the cradle of the first juridical philosophical thinker uncontroversial Portuguese, D. Álvaro Pais (1275/80-1353): was he born in Portugal or in Galicia, in Spain? And, without wishing to claim any portugality, even spiritual, it is known that the master of the second scholastic Francisco Suárez (1548-1619), Doctor Eximius, being Grenadian, had his PhD in Évora, Portugal, taught in Coimbra and died and is buried in Lisbon, in the Church of San Roque. By these examples, Portugal seems fertile in philosophers of law not born in its territory. But they are just two cases.

Breaking the placid traditional line, however, the Renaissance period gave way to another kind of preferences or 
Esta revista forma parte del acervo de la Biblioteca Jurídica Virtual del Instituto de Investigaciones Jurídicas de la UNAM www.juridicas.unam.mx

http://biblio.juridicas.unam.mx

PAULO FERREIRA DA CUNHA

anxieties, at least in their formulation and explicit style. And after that scientists and technocrats took the fortress of Law. But the decline of the essential concern of legal philosophy and even of its university studies does not mean death. In the shadow and silence, and even resistance, there has always been researchers and thinkers faithful to the tradition of reflexive law.

Legal philosophy, cultivated among us in a non-academic way ('implicit' in the terminology of Miguel Reale) very early (at least since the fourteenth century), was officially introduced in Portugal in its rationalist formula by Pombal's reform of the University (1772), then assuming the name "Natural Law (which, as is well known, in Spain still remained for a couple of centuries). Even in the late nineteenth century, the philosophy of law had between us host among pure philosophers, and was taught at the High Schools, in the discipline of Philosophy. Cunha Seixas, pioneering Portuguese philosophy, who served until his death as a lawyer, did not disdain to write legal philosophical pages for the purpose of teaching in high schools and normal schools. The second half of the nineteenth century assists in Portugal to a major outbreak: it is the time of positivism and scientism.

In the early twentieth century, however, positivists had succeeded in imposing on curriculum reform, in 1901. It produced a change of name and content in the chair of the first year of law school: it became Sociology General and Philosophy of Law. And integrated into a whole plan that was to precede the study of the positive law of sociological Prolegomena. Not a bad idea, if it was not largely ideological in the sense of propaganda...

The positivist reform plan for law studies, which followed the establishment of the First Portuguese Republic in 1910 (very inspired on the previous Brazilean one), abolished the Philosophy of Law, and soon after created the second Lisbon Law Faculty, a leading school whose name printed on the philosophical conception of its creators: Faculty of So- 
Esta revista forma parte del acervo de la Biblioteca Jurídica Virtual del Instituto de Investigaciones Jurídicas de la UNAM www.juridicas.unam.mx

http://biblio.juridicas.unam.mx

LUSOPHONE JURISPRUDENCE IN IBEROAMERICAN LEGAL PHILOSOPHY

cial Studies and Law. Obviously the new institution appeared devoid of legal philosophy. The rallying cry of turning back to the roots emerge from the student of the Faculty of Law of Coimbra (later to become one of the most solid and reputable historians of law), Paul Merea, still in 1910, through a conference, and later two articles (the latter returning to the initial conference, and published in 1913). But it would take more than twenty years that seed bear fruit. Restored in 1936-1937, with Cabral Moncada, companion of studies of Merea, although primarily only experimentally, the discipline has counted worthy successors to the legacy of these masters, although it has been subject to further vicissitudes, never finished because of the antiphilosophical prejudice, nowadays enhanced by prevailing climate of technological cretinism (as the French sociologue Jean Duvignaud puts it).

\section{NON JURIDICAL JURISPRUDENCE}

But more interesting than the official Jurisprudence is the reflection on Law by people who are not professional jurists. Poets (like Teixeira de Pascoaes or even Fernando Pessoa), fiction writers (Raul Brandão), essaysts (Orlando Vitoriano, Afonso Botelho, Dalila Pereira da Costa) pure philosophers (Sampaio Bruno, Leonardo Coimbra), heterodox thinkers (Agostinho da Silva), etc., although this categories are not frozen (some of them cultivated many literary genres).

It should be noted that one of the appealing and attractive characteristics of Portuguese Philosophy is its "orality" and even a certain amount of memorialism. There is a patent alive dialogue with the reader, which is made of direct questioning, storytelling that assumes the art of saying what you mean, so often very beautifully (and that Leonardo Coimbra was a master on this: even a master of oral suspence...) but accurate. No fatuous blisters and particularly uncomplicated and purposeful verbal intellectualism. 
Esta revista forma parte del acervo de la Biblioteca Jurídica Virtual del Instituto de Investigaciones Jurídicas de la UNAM www.juridicas.unam.mx

http://biblio.juridicas.unam.mx

PAULO FERREIRA DA CUNHA

The ideas of these authors about law, justice, etc. are normally original, and they do not sacrifice to the academic idols. Although the autodidactism sometimes weakens their arguments in the context of an academica debate, of course (one might be tempted to argue that the author didn't study law...). There are a certain esoteric aura in some writings, even more philosophical-political ones (such as in Dalila Pereira da Costa and Sampaio Bruno). New authors of this school, like Braz Teixeira, seem to make a bridge between the non academic and the academic fields. The last idea is the contruction of a theory of juridical rationality, opposed to a simple methodology of law...

\section{BRAZILEAN MEMoIRS}

The evolution of the Brazilian legal philosophy has had some parallels with the Portuguese one, at some point to be considered 'one of the virtualities of Portuguese philosophy who found a suitable opportunity and ran its course. Eventually this is an ethnocentric statement. And other theoretical solutions could be found...

Let's just recall that, at the level of the aforementioned legal philosophy, the fact that the Jesuits have strongly influenced the colonization period. And they generally marked an essentially Thomistic philosophy, which had repercussions on the traditional Brazilian Philosophy of Law. However, now we have in Brazil as many schools of thought as it would be imaginable, or even more. The creativity is a rule, there, and the intellectual prejudice is almost absent...

Academically, legal philosophy was introduced when creating legal courses in Brazil (São Paulo and Olinda, the latter then transferred to Recife), by the Law of August 11, 1827 (five years after the establishment of the empire) through a chair of third year, Natural Law. But it seems that in São Paulo a interdisciplinary chair opened the classes, mixing Philosophy of law (represented by Natural 
Esta revista forma parte del acervo de la Biblioteca Jurídica Virtual del Instituto de Investigaciones Jurídicas de la UNAM www.juridicas.unam.mx

http://biblio.juridicas.unam.mx

LUSOPHONE JURISPRUDENCE IN IBEROAMERICAN LEGAL PHILOSOPHY

Law) and Public Law, mainly Constitutional. The professor was a Portuguese, the Judge Avelar Brotero, brother of the Portuguese Professor of Botanics, that poses to history in Coimbra's botanic Garden. We may see Brotero with Christ cross in a larg full body portrait in a main corridor of São Paulo's Faculty of Law.

However, also in Brazil the positivist wave grew during the nineteenth century in reaction to the 'scholastic' tradition, then having represented major role in the Faculty of Law of São Paulo and the one of Recife, whose leader was Tobias Barreto, in the decade 1870, although Tobias was against August Comte's ideas: actually, essentially influenced by Germanic literature. Rui Barbosa, intellectual and tribune which is still a myth, proposed replacing the chair of the Natural Law by Sociology.

And the Brazilian Republic (November 15, 1889), which adopted the Comtean slogan "order and progress", embracing the globe, while quenching chairs of Ecclesiastical Law, replaced coherently Natural Law by History and Philosophy of Law. This chair, however, does not usually constitute more than a precursor (little known, though) of the identification of legal philosophy and legal theory or methodology in formulations similar to those we now know well.

Advocates of legal philosophy in the classic way still existed, of course, like João Mendes Júnior and Soriano Sousa. Although already in 1905 an introduction to law, under the title The Truth as Rule Actions, had decisively attacked the already prevailing positivism, only since the 40s, and perhaps especially up in the aftermath of World War II, overcoming positivism at the philosophical level, will be consummated in Brazil.

The permanence of Thomistic thought in Brazil appears to us differently evaluated by the authors. If, for Nelson Saldanha, "his action produced a continuous line that was not interrupted ever leaving their mark on the social and political theory, as well as in the field of law", according to Miguel Reale, even overcoming of positivism, at the begin- 
Esta revista forma parte del acervo de la Biblioteca Jurídica Virtual del Instituto de Investigaciones Jurídicas de la UNAM www.juridicas.unam.mx

http://biblio.juridicas.unam.mx

PAULO FERREIRA DA CUNHA

ning in 1940, was made "without going back to the Natural Law of Thomist inspiration ". However, this author finishes significantly its glimpse of Brazilian legal philosophy of the last hundred years with a reference to this current, noting that "it deserves to be remembered significant inspiration of Thomistic studies' that highlights Tristan Athayde (pseudonym of Alceu Amoroso Lima), Edgar Godoi Leonardo da Mata Machado and Van Acker.

Nowadays, in addition, of course, we see the traditional flow and attractiveness of new analytical and neopositivists (the kelsenianism has a certain role too), plus the new wave of "alternative law", postmodern law, legal culturalism, neoconstitutionalism, pluralism, etc.. And even more specifically the legal tridimensionalism, current or confluence of currents that most associate with the image Brazil Jurisprudence.

But to what extent this last identification is not due to the enormous international prestige Miguel Reale?

\section{What is REALLY in Common?}

We have to make a reflective pause: how can we say that the specific feature of a Lusophone Jurisprudence is either something politically and culturally common, or parallel pathways after the independence of Brazil? How to identify the Lusophone Jurisprudence? Only with a more European version, or a tropical readapted-Aristotelianism Thomism on law matters? These items seem really scarce and poorly differentiated while national or cultural legal philosophy. That traditional way is not the way...

In our various previous studies on these questions, we followed the trail of a possible specific Portuguese thinking in multiple authors, particularly between the eighteenth and nineteenth centuries. This is not the place to present the findings on each of them. In fact, the most salient elements in non academics (university professors also studied law, but in general seemed to prevail in cosmopolitan eclec- 
Esta revista forma parte del acervo de la Biblioteca Jurídica Virtual del Instituto de Investigaciones Jurídicas de la UNAM www.juridicas.unam.mx

http://biblio.juridicas.unam.mx

LUSOPHONE JURISPRUDENCE IN IBEROAMERICAN LEGAL PHILOSOPHY

ticism, or adherence to a foreign idea more or less fashionable or sujetive) were not Aristotelianism or Thomism, essentially, but more or less original (sometimes apt to provoke some estrangement between the lawyers, as is the case, among several possible, of the nomenclature used by Delfim Santos and Álvaro Ribeiro). In general, these authors were worrying about what we would call Justice, equity and the like.

But the question, in view of the actual data, is quite strong, and distressing.

The most important doubt is this one: is it fair, and scientifically suitable, acceptable, that someone (certainly acting with the best intentions, we may admit) may make a choice among the different manifestations of juridical philosophy in one country or group of countries, and using his or her own perspective (a subjective one), show subsequently the world a face of that country or culture in what concerns Jurisprudence that may not be shared by many people... in the limit, all the others? Is it fair to make that choice?

Again, the Portuguese evolution may be an illustrative and eloquent example.

We think not to be too far from the reality if we say that before the work of António Braz Teixeira (correspondent member of the Brazilean Academy of Letters), only a certain kind of works seemed to be admited as being part of Portuguese philosophy. It seemed that it was a movement, a school, with a certain programmatic and even ideological aim. However, after the studies of this thinker, a contemporary one, it seems that Portuguese philosophy changed: now, it is generally concieved as all the speculative thought exposed in Portuguese, in priciple made by Portuguese citizens... Because it cannot be Portuguese philosophy some philosophical works in Portuguese language but by other nationals from other countries... And there are many African countries with Portuguese as official language, apart from the case of Brasil, East Timor and other parts of the 
Esta revista forma parte del acervo de la Biblioteca Jurídica Virtual del Instituto de Investigaciones Jurídicas de la UNAM www.juridicas.unam.mx

http://biblio.juridicas.unam.mx

PAULO FERREIRA DA CUNHA

world where it is not official language but it is spoken, like Macao, in China (at least partially) or Galicia, in Spain, acording to some observers...

But even this new vision, more wide, more open, seems to bring us some problems.

First, authors like Silvestre Pinheiro Ferreira, Portuguese by language and nationality, but also very close to Brazil (where he lived and ruled as a Portuguese minister of king John the VIth, from 1810 to 1821), wrote sometimes in French, and published books in France. Why should the French works of Portuguese (or Brazilian or others...whose mother Language is Portuguese) be aside Portuguese philosophy? This specific text itself, should it be put away from it, because it is in English? Does the vehicule, the language itself, although nicely emphasised always as "house of being" (Heidegger), is the mean more important than the message, the spirit of a national or cultural philosophy? Or may we suspect that the obstination in the language hides a certain vagueness of the substance? Terrible tempatation, this last thought.

Secondly, Portuguese language is shared by many countries, as we know. If language is the most important, how can we distinguish a Portuguese philosophy from a Brazilean, an Angolan or a Timorease one? It seems that language is not enough. This leads us to a more complex question: would we prefer a multilinguistic paradigm, for example the bilinguistic one of Hisponamerican Jusrisprudence? Here the criterium would be a cultural one, although Portuguese and Castillan are two very similar languages. The main question, here, seems to be: either to build a step on a Lusohone Jurisprudence with a peculiar being, and then integrate it in a higher and wider Hispanoamerican Jurisprudence, or to connect directly all the different national philosophies or even atomistic philosophers or philosophic movements in a large net. Not a national one, even nor a linguistic first step. We may discuss 
Esta revista forma parte del acervo de la Biblioteca Jurídica Virtual del Instituto de Investigaciones Jurídicas de la UNAM www.juridicas.unam.mx

http://biblio.juridicas.unam.mx

LUSOPHONE JURISPRUDENCE IN IBEROAMERICAN LEGAL PHILOSOPHY

the pertinence of this in philosophical, cultural, sociological and even geopolitical terms.

Thirdly, it is quite easy to put into Portuguese (or in Castillian...or in many other languages) with more or less skills and pains, a fully imported philosophy. A Portuguese mental translation of a foreign philosophy (and eventually very strange to the ways of Lusophone people: for example, a cold, purely rationalistic one, if we admit that our peoples are more sentimental, etc.) is of course possible. The question is: would it still be Portuguese, Brazilian, Angolan, etc... Lusophone philosophy?

Our personal answer is negative. But we must go further. We think that it is not profitable to think on a national or civilizational philosophy if it has nothing more than the linguistic common topic. It has to have some peculiar common soul, spirit, idea. The linguistic criterium is not enough at all.

It is possible that a Portuguese, a Mexican, a Brazilian, a Mozambican, a Chilean... write in English, in German or in Chinese. Of course they have to adapt to certain more or less peculiar aspects of the language they must use. But the container doesn't completely change the contained. And let's allways remember that Spinoza, even Spinoza itself seemed to have thought in a language different from the languages he used to write. This is very important. One think is to think directly in one language, another one is to translate our own thoughts to another language. And even when the thinker thinks immedialty in another language, the background of his or her motherlanguage may be is still there. An hypothesis to the neurolinguists, at least.

We may use another language, but if we are faithfull to our cultural roots, they still create their own civilizational centred philosophies.

Finally, if it is true that there are many similarities between some Portuguese and Brazilean philosophical authors, the constitution of a Luso-Brasilean jurisprudence still awaits for its theorists. And even more complicated seems to be a general Hispanoamericam Jurisprudence. Al- 
Esta revista forma parte del acervo de la Biblioteca Jurídica Virtual del Instituto de Investigaciones Jurídicas de la UNAM www.juridicas.unam.mx

http://biblio.juridicas.unam.mx

PAULO FERREIRA DA CUNHA

though this empire where the sun shines forever was maybe a version of the Vth Empire in the profetic philosophy of Agostinho da Silva.

This general common jurisprudence risks to be very vague. But we are of course open to the possibility... Maybe it would be more cautious if we build first our national philosophies (the return to sovereignity seems to regain adepts in a world of impious globalisation), discovering its main features. After that, the next step would be to look for the family ties - first the Lusophone and then the Hispanoamerican.

But never forgetting that some national philosophies may have other connetions. For example, the Portuguese one with the Mediterranic thinking, the South European thinking.

In this case, it is not a question of language only. Of course there is Latinity. But Latinity is only a part of the legacy of the old mare nostrum of the Roman Empire... Even other bounds are possible. Let's never forget that an agent of the French Convention said Portuguese would be, at the time, French, if they could not be Portuguese. Or let's remember that the best Portuguese elite of all times was from English-Portuguese birth: the sons of the Portuguese John the first and the British D. Filipa, from the house of Lancaster. And that "High Generation" was the seed of Discoveries... Many possibilities are possible, in what concerns social and cultural and sentimental affinities. But what we must have in mind in this context are the philosophical affinities.

Even without the American scene, Portuguese and Spanish thinkers should increase their dialogue, and go further not only in the archeology of freedoms, but also in the analysis of the thoughts.

We are nowadays, in all our countries, too fascinated with what comes from the main poles of the jurisprudence production, Germany and the Anglo-Saxon world. They are excellent, in their ways. But there is more, Horatio... Portuguese and Spanish and other languages thinkers have also think- 
Esta revista forma parte del acervo de la Biblioteca Jurídica Virtual del Instituto de Investigaciones Jurídicas de la UNAM www.juridicas.unam.mx

http://biblio.juridicas.unam.mx

LUSOPHONE JURISPRUDENCE IN IBEROAMERICAN LEGAL PHILOSOPHY

ers. They may be original, and not only comments on those other ones, with more media reverence and bestsellers.

I am not purposing to make a new Tordesillas treaty, by which we Portuguese speakers and Castillan speakers would share the world. But I am certainly suggesting that we may think how to preserve our intellectual and even educational and editing traditions, in a world more and more formated one way. And the intellectual globalisation is not at all ours, nor even flexible to our way of being and of thinking.

The fact we were supposed to be in Brazil speaking English among us is a very concrete illustration of what is happening to our civilization. A danger already prophecised some decades ago by the Brazilean sociologist Gilberto Freyre.

VII. BIBLIOGRAPHY

Albuquerque, M. de (with Eduardo Vera Cruz), Da Igualdade. Introdução à Jurisprudência, Coimbra, Almedina, 1993.

Almeida SAnTos, A., Que Nova Ordem Mundial?, Lisbon, Campo da Comunicação, 2008.

ARISTOTLE, Nicomachean Ethics.

AYREs DE BRITO, C., O Humanismo como Categoria Constitucional, Belo Horizonte, Forum, 2007.

Ayres De Brito, C., Teoria da Constituição, Rio de Janeiro, Forense, 2006.

BAPTISTA MACHADO, J., Introdução ao Direito e ao Discurso Legitimador, reimp., Coimbra, Almedina, 1985.

BAPTISTA PEREIRA, M., Modernidade e Secularização, Coimbra, Almedina, 1990.

BARcellos, A. P., A Eficácia Jurídica dos Princípios: O Princípio da Dignidade da Pessoa Humana, Rio de Janeiro, Renovar, 2002. 
Esta revista forma parte del acervo de la Biblioteca Jurídica Virtual del Instituto de Investigaciones Jurídicas de la UNAM www.juridicas.unam.mx

http://biblio.juridicas.unam.mx

PAULO FERREIRA DA CUNHA

BARTHes, R., Mythologies, Paris, Seuil, 1957.

BAUMANN, Z. (2010), Legislators and Interpreters (On Modernity, Post-modernity and Intellectuals), Cambridge, Polity Press, 1987, Brasil. ed., transl. by Renato Aguiar, Legisladores e Intérpretes, Rio de Janeiro, Zahar.

BAYLIN, B., The Ideological Origins of the American Revolution, 2nd ed., London, The Belknap Press of Harvard University Press, 1992.

BITTAR, E. C. B., O Direito na Pós-Modernidade, Rio de Janeiro, Forense, 2005.

Boff, L., Fundamentalismo. A Globalização e o Futuro da Humanidade, Rio de Janeiro, Sextante, 2002.

Bonavides, P., Curso de Direito Constitucional, 2nd ed., São Paulo, Malheiros, 2008.

Bonavides, P., Do Estado Liberal ao Estado Social, 7th ed., São Paulo, Malheiros Editores, 2004.

BRuno, S., O Encoberto, ed. de Porto, Lello, 1983.

CAlvino, I., Lezioni Americane - Sei proposte per il prossimo Milenio, 4a. ed. Port. transl. by José Colaço Barreiros, Seis Propostas para o Próximo Milénio, Lisbon, Teorema, 2002.

CARdoso DA CostA, J. M. M., O Principio da Dignidade da Pessoa Humana na Constituição e na Jurisprudência Constitucional Portugueses, in Direito Constitucional. Estudos em Homenagem a Manoel Gonçalves Ferreira Filho, coord. Sérgio Resende de Barros e Fernando Aurélio Zilveti, São Paulo, Dialética, 1999.

CARDucci, M., Por um Direito Constitucional Altruista, Porto Alegre, Livraria do Advogado Editora, 2003.

CARMEN ROVIRA, M. del, Eclecticos portugueses del siglo XVIII $y$ algunas de sus influencias en America, México, 1958. 
Esta revista forma parte del acervo de la Biblioteca Jurídica Virtual del Instituto de Investigaciones Jurídicas de la UNAM www.juridicas.unam.mx

http://biblio.juridicas.unam.mx

LUSOPHONE JURISPRUDENCE IN IBEROAMERICAN LEGAL PHILOSOPHY

CASSIRER, E., La Philosophie des Lumières, trad. fr. , Paris, Fayard, 1966.

CAstro Osório, A., A Minha Pátria, new ed., Preface by Teresa Simões, Sintra, Colares Editora, 2008.

CerejeIRA, Doutor M. G., O Renascimento em Portugal. I. Clenardo e a Sociedade Portuguesa, 4th ed., Coimbra, Coimbra Editora, 1974.

Chamon Junior, L A, Teoria Geral do Direito Moderno. Por uma Reconstrução Crítico-Discrusiva na Alta Modernidade, 2.nd ed., Rio de Janeiro, Lumen Juris, 1972.

ChÂtelet, F. (dir), Les Lumières, Paris, Hachette, 1972.

Chaunu, P., La Civilisation de l'Europe des Lumières, Paris, Flammarion, 1982.

Constant, B., De la Liberté des Anciens comparée à celles des Modernes, nova ed., Paris, Le Livre de Poche, 1980.

DIAS, J., Estudos de Antropologia, vol. I, Lisbon, Imprensa Nacional - Casa da Moeda, 1990.

DiAs, J., O Essencial sobre os Elementos Fundamentais da Cultura Portuguesa, Lisbon, Imprensa Nacional-Casa da Moeda, 1985.

FERREIRA DA CunHA, P., "As Liberdades Tradicionais e o Governo de D. João VI no Brasil. Ensaio Histórico-Jurídico Preliminar", Quaderni Fiorentini per la Storia del Pensiero Giuridico Moderno, num. 32, 2003.

FERREIRA DA CUnHA, P., Do Brasil na Arqueologia das Liberdades, in Convergências \& Afinidades. Homenagem a António Braz Teixeira, Lisbon, Centro de Estudos de Filosofia da Faculdade de Ciências Humanas da Universidade Católica Portuguesa e Centro de Filosofia da Universidade de Lisbon, 2008.

FERREIRA DA CUNHA, P., Liberdade, Ética e Direito, Revista "Nomos. Revista do Curso de Mestrado da Universi- 
Esta revista forma parte del acervo de la Biblioteca Jurídica Virtual del Instituto de Investigaciones Jurídicas de la UNAM www.juridicas.unam.mx

http://biblio.juridicas.unam.mx

PAULO FERREIRA DA CUNHA

dade Federal do Ceará”, vol. 28. 2, Fortaleza, 2008 / 2, 2008.

FERreira DA Cunha, P., El Derecho y la Razón en Sto. Tomás de Aquino. Para una Relectura Jusfilosófica, in "Actas del 1o. Congreso nacional de Filosofia Medieval“ Zaragoza, 1992.

FERREIRA DA CunHA, P., Geografia constitucional. Sistemas juspoliticos e globalização, Lisbon, Quid Juris, 2009.

FERREIRA DA CUNHA, P., "Aristóteles: Filosofia do homem ética e politica”, Revista Internacional d'Humanitats, Barcelona, year VIII, num. 8: http://www.hottopos.com/rih8/pfc.htm\#_ftn1, 2005.

FERREIRA DA CunHA, P., Mysteria Iuris. Raizes mitosóficas do pensamento jurídicO-político português, Porto, Legis, 1999.

FERREIRA DA CUNHA, P., "Raízes das Liberdades - Para um diálogo histórico-constitucional", Revista da Faculdade de Direito da Universidade do Porto, III, 2006.

Gomes CAnotilho, J. J., "O Círculo e a Linha. Da 'liberdade dos antigos' à liberdade dos modernos' na teoria republicana dos direitos fundamentais (I parte)", O Sagrado e o Profano, Homenagem a J. S. da Silva Dias, Revista de História das ideias, num. 9, III, Coimbra, 1987.

JAeGer, W., Paideia, Die Formung des Griechichen Menschen, Berlin, Walter de Gruyter, 1936, Port. transl. by Artur M. Parreira, Paideia. A Formação do Homem Grego, Lisbon, Aster, 1979.

LAUAND, J., Filosofia, Linguagem, Arte e Educação, São Paulo, ESDC / CEMOROC - EDF - FEUSOP / Factash Editora.

Malato, M. L. (2009), Manual Anti-Tiranos. Retórica, Poder e Literatura, Porto Alegre, Livraria do Advogado Editora, 2007. 
Esta revista forma parte del acervo de la Biblioteca Jurídica Virtual del Instituto de Investigaciones Jurídicas de la UNAM www.juridicas.unam.mx

http://biblio.juridicas.unam.mx

LUSOPHONE JURISPRUDENCE IN IBEROAMERICAN LEGAL PHILOSOPHY

MARÍAs, J., Historia de la Filosofia, 4th ed., Madrid, Manuales de la Revista de Occidente, 1948.

MotA DE SOUSA, C. A. et al., Direito e fraternidade, LTR, 2008.

OTERO PARGA, M., Valores constitucionales. Introducción a la filosofía del derecho: axiologia jurídica, Santiago de Compostela, Universidade de Santiago de Compostela, 1999.

PEREIRA MEnAUT, A-C, "Constitución, princípios, valores", Separata de Dereito. Revista Xurídica da Universidade de Santiago de Compostela, vol. 13, num. 1, 2004.

Pulido Valente, V., Portugal. Ensaios de História e de Politica, Lisbon, Aletheia, 2009.

Quental, A. de, Causas da Decadência dos Povos Peninsulares, 6th ed., Ulmeiro, 1994.

REALE, M., Invariantes Axiológicas, v.g. in Paradigmas da Cultura Contemporânea, 1st ed, , São Paulo, 1999.

REALE, M., "Liberdade Antiga e Liberdade Moderna", Revista da Universidade de São Paulo, num. 1, p. 5 et sq.., in ex in Horizontes do Direito e da História, 2nd. ed., São Paulo, Saraiva, p. 17 et sq, 1977.

REAlE, M., Lições Preliminares de Direito, 10a. ed. revista, Coimbra, Almedina, 1982.

REIS, A., "Os Valores Republicanos Ontem e Hoje", in Reis, António de (org.), A República Ontem e Hoje, II Curso Livre de História Contemporânea, Lisbon, Colibri, 2002.

RESTA, E., Il Diritto Fraterno, Roma-Bari, Laterza, 2002.

REYS MATE AND NiEWÖHNER, F. (cords), La Ilustración en España y Alemania, Barcelona, Anthropos, 1989.

Romano De Sant'AnnA, A., Tempo de delicadeza, Porto Alegre, L\&PM, 2007.

SAVATER, F., Ética para Amador, Barcelona, Ariel, 1991. 
Esta revista forma parte del acervo de la Biblioteca Jurídica Virtual del Instituto de Investigaciones Jurídicas de la UNAM www.juridicas.unam.mx

http://biblio.juridicas.unam.mx

PAULO FERREIRA DA CUNHA

VALLET DE GOYTISOLO, J., Esquema Introductivo para una Metodologia de la Ciencia Expositiva y Explicativa del Derecho, Real Academia de Jurisprudencia y Legislacion, Madrid, 1999.

VÉlez Rodríguez, R., A Análise do patrimonialismo através da Literatura Latino-Americana. O Estado gerido como bem familiar, Rio de Janeiro, Documenta Histórica Editora / Instituto Liberal, 2008. 